\title{
PENGEMBANGAN MEDIA PEMBELAJARAN INTERAKTIF BERBASIS CONTEXTUAL TEACHING AND LEARNING PADA MATA PELAJARAN BAHASA INGGRIS
}

\author{
Nurhidayah $^{1}$, R. Mursid ${ }^{2}$, Ibrahim Gultom ${ }^{3}$ \\ ${ }^{1}$ Sekolah Menengah Atas Negeri 20 Medan, Sumatera Utara \\ ${ }^{2,3}$ Pascasarjana Universitas Negeri Medan \\ nurhidayah@gmail.com ${ }^{l}$
}

\begin{abstract}
Abstrak: Penelitian pengembangan ini bertujuan untuk mengembangkan media belajar dalam pembelajaran Contextual Teaching And Learning. Media pembelajaran interaktif berbasis CTL ini mengembangkan materi Hope and Dream dengan subjek penelitian pada SMA Negeri 20 Medan. Teknik pengumpulan data menggunakan metode wawancara, angket tanggapan, lembar observasi, angket pengamatan, dan dokumentasi. Penelitian pengembangan media melalui beberapa tahap yaitu tahapan defenisi dilakukan wawancara analisis kebutuhan dan masalah yang ada pada lokasi penelitian pengembangan. Tahap kedua dilakukan perancangan media berupa naskah media yang akan dikembangakan. Tahap terakhir adalah tahap pengembangan dilakukannya penilaian pada hasil media yang dikembangakan kemudian diuji cobakan terhadap siswa skala kecil dan skala besar. Berdasarkan hasil penelitian pengembangan media pembelajaran berupa media interaktif berbasis CTL layak digunakan dalam pembelajaran. Terbukti dengan penilaian oleh ahli materi mendapat nilai rata-rata 4.48 dengan tingkat persentase kelayakan $89.58 \%$ dengan kategori "Layak", ahli media mendapat nilai rata-rata 4.27 dengan tingkat persentase kelayakan $85.36 \%$ dengan kategori "Layak", ahli desain pembelajaran 3.78 dengan tingkat persentase kelayakan 75.56\% dengan kategori "Layak" serta pendapat siswa pada uji skala kecil 3.64 dengan tingkat persentase kelayakan 74.67\% dengan kategori "Layak" selanjutnya uji skala besar 3.65 dengan tingkat persentase kelayakan $75.12 \%$ dengan kategori "Layak".
\end{abstract}

Kata Kunci: media pembelajaran interaktif, contextual teaching and learning, bahasa inggris

Abstract: This development research aims to develop learning media in learning Contextual Teaching And Learning. CTL-based interactive learning media develops Hope and Dream material with research subjects at SMA Negeri 20 Medan. Data collection techniques using interview methods, response questionnaires, observation sheets, observation questionnaires, and documentation. Media development research through several stages, namely the definition stage interviews conducted analysis of needs and problems that exist at the location of research development. The second stage is media design in the form of a media script that will be developed. The last stage is the stage of development to do an assessment of the results of the developed media then tested on small and large scale students. Based on the results of research into the development of instructional media in the form of interactive media based on CTL is suitable for use in learning. Evidenced by the assessment by the material experts got an average value of 4.48 with a level of eligibility percentage $89.58 \%$ with the category "Eligible", media experts received an average value of 4.27 with a percentage level of eligibility $85.36 \%$ with the category "Eligible", learning design expert 3.78 with a level the percentage of eligibility $75.56 \%$ with the category "Eligible" and students' opinions on the small scale test 3.64 with a level of eligibility percentage $74.67 \%$ with the category "Eligible" then the large scale test of 3.65 with a percentage level of eligibility of $75.12 \%$ with the "Eligible" category.

Keywords: interactive learning media, contextual teaching and learning, English

\section{PENDAHULUAN}

Banyak sekali sekolah di Indonesia yang mempunyai banyak fasilitas pendukung namun kurang bermanfaat karena tidak adanya media pembelajaran yang akan digunakan. Sebagaimana halnya pada SMA Negeri 20 Medan, dalam sekolah tersebut sangatmenfasilitasi guru untuk menggunakan media pembelajaran dalam setiap proses pembelajarannya. Dan juga fasilitas ruang komputer yang memadai dengan jumlah komputer yang banyak dengan kecanggihannya. Fasilitas yang memadai tersebut dapat digunakan sewaktu-waktu oleh siswa dan guru.

Undang-undang No 20 tahun 2003 tentang Sistem Pendidikan Nasional mengemukakan seiring dengan perubahan paradigma pembelajaran, maka keberhasilan 
kegiatan pembelajaran tidak hanya ditentukan oleh faktor pendidik, melainkan sangat dipengaruhi oleh keaktifan peserta didik dengan pendidik sebagai sumber belajar pada lingkungan belajar. Dengan demikian, peserta didik seharusnya tidak belajar dari pendidik saja (teacher oriented), tetapi juga dari berbagai sumber belajar yang tersedia dilingkungannya.

Melihat keterbatasan yang melekat pada media pembelajaran disekolah, maka sudah saatnya media pembelajaran ditingkatkan kualitasnya atau bahkan diganti dengan mengembangkan suatu media pembelajaran yang lebih inovatif sekaligus interaktif, diantaranya adalah media pembelajaran yang dirancang dengan menggunakan bantuan komputer. Sebuah pembelajaran akan menarik perhatian siswa jika ada keterpaduan antara pemilihan strategi atau metode pembelajaran dengan media pembelajaran yang sesuai dengan materi pelajaran yang akan disajikan.

Pada pembelajaran di SMA Negeri 20 Medan tingkat keberhasilan terhadap pembelajaran masih belum maksimal. Sehingga sangat diperlukan adanya daya tarik dalam kegiatan pembelajaran yakni adanya pengembangan media pembelajaran yang akan menciptakan daya tarik siswa untuk belajar.

Reigeluth (1983: 20) menyatakan bahwa hasil belajar secara umum dapat dikategorikan menjadi 3 indikator, yakni: 1) efektivitas pembelajaran yang biasanya diukur dari tingkat keberhasilan (prestasi) siswa dari berbagai sudut, 2) efisien pembelajaran yang biasanya diukur dari waktu belajar atau biaya pembelajaran, dan 3) daya tarik pembelajaran yang biasanya diukur dari tendensi siswa ingin belajar secara terus menerus.

Karakteristik dari siswa SMA Negeri 20 Medan sangat membutuhkan pembelajaran dengan menggunakan media pembelajaran interaktif. Para peserta didik sangat membutuhkan pembelajaran yang tidak hanya mendengarkan penjelasan dari guru, namun juga sangat dibutuhkan adanya penggunaan media interaktif antara peserta didik dengan media pembelajaran yang telah diterapkan. Oleh sebab itu perlu adanya pengembangan terhadap media pembelajaran sehingga meningkatkan motivasi peserta didik dalam belajar, khususnya dalam pembelajaran Bahasa Inggris. Media yang akan dikembangkan berupa media pembelajaran interaktif. Dengan menggunakan pembelajaran interaktif yang akan meningkatkan motivasi belajar peserta didik, dan peserta didik akan dapat melakukan pembelajaran secara mandiri.

Hasil pengamatan dari angket yang diisi oleh guru bahasa Inggris di SMA Negeri 20 Medan menunjukkan bahwa $100 \%$ dari guru-guru membutuhkan media pembelajaran interaktif dalam proses pembelajaran agar proses pembelajaran berjalan lebih efektif dan menarik. Dari hasil wawancara dengan guru Bahasa Inggris secara khusus menunjukkan bahwa masih menggunakan metode pembelajaran ceramah dan media yang sederhana sehingga siswa cenderung pasif selama pembelajaran. Mereka mengaku kesulitan memperoleh media pembelajaran yang efektif untuk pelajaran Bahasa Inggris disekolah sehingga kegiatan pembelajaran kurang efektif dan peserta didik merasa kesulitan dalam memahami materi yang disampaikan. Dari angket yang disebar kepada siswa yang diambil sebagai sampel, $100 \%$ siswa menyatakan membutuhkan media pembelajaran interaktif yang dapat mereka jadikan sebagai sarana pembelajaran secara individual. Siswa merasa jenuh dengan pola pembelajaran Bahasa Inggris sehingga tidak heran banyak siswa yang tidak memperhatikan penjelasan guru. Rendahnya motivasi belajar siswa dalam pembelajaran Bahasa Inggris tersebut menyebabkan rendahnya hasil belajar Bahasa Inggris.

Berdasarkan uraian diatas, banyak hal yang dapat dijadikan sebagai salah satu media pembelajaran, khususnya untuk pembelajaran Bahasa Inggris. Salah satunya yaitu menggunakan media pembelajarn interaktif yang berisikan materi Bahasa Inggris yang disajikan semenarik mungkin. Maka dari itu peneliti tertarik mengembangkan media pembelajaran interaktif Bahasa Inggris pada materi "Hopes and Dreams" untuk siswa SMA Negeri 20 Medan yang sesuai dan tepat sehingga menambah daya tarik siswa dan memotivasi siswa dalam memahami materi pelajaran. Selain itu untuk membuat kegiatan pembelajaran lebih mengaktifkan siswa, kerjasama siswa, dan meningkatkan kreatifitas siswa. Media berbasis komputer merupakan kombinasi empat komponen suara, gambar, video dan teks. Memanfaatkan kemajuan teknologi informasi dan komunikasi, diharapkan mampu memecahkan masalah dalam kegiatan pembelajaran. Salah satu media 
yang sesuai dengan perkembangan teknologi dan yang dapat digunakan dalam proses pembelajaran ini adalah Adobe Flash Professional CS6.

\section{Belajar dan Pembelajaran}

Tujuan pembelajaran adalah suatu deskripsi tentang perubahan tingkah lakusiswa setelah berlangsung pembelajaran.Menurut Dick \& Carey (2009), menjelaskanbahwa tujuan pembelajaran harus dapat diamati, seperti 'menyusun', 'menggunakan', atau 'mendemonstrasikan'. Bukan sekedar 'memahami', 'mengetahui', dan 'merasakan' yang tidak dapat diamati oleh mata. Jadi proses pembelajaran harus terkonsep dengan baik,guru harus mampu menyusun dan merumuskan tujuanpembelajaran secara teliti dan detail.

Tujuanpembelajaran adalah perubahan tingkah laku yang positif dari pesertadidik, seperti perubahan yang secara psikologis akan tampil dalam tingkahlaku (overed behaviour), yang dapat diamati oleh alat indra oleh oranglain baik tutur kata, motorik, dan gaya hidup.

\section{Pembelajaran Bahasa Inggris SMA}

Bahasa merupakan alat komunikasi yang penting bagi manusia sehingga dalam kenyataannya bahasa menjadi aspek penting dalam melakukan sosialisasi atau berinteraksi sosial. Dengan bahasa manusia dapat menyampaikan berbagai berita, pikiran, pengalaman, gagasan, pendapat, perasaan, keinginan, dan lain-lain kepada orang lain."

Mata pelajaran Bahasa Inggris mempunyai karakteristik yang berbeda dengan mata pelajaran eksakta atau mata pelajaran ilmu sosial yang lain. Perbedaan ini terletak pada fungsi bahasa sebagai alat komunikasi. Hal ini mengindikasikan bahwa belajar Bahasa Inggris bukan sekedar belajar kosakata dan tatabahasa dalam arti pengetahuannya, tetapi harus berupaya menggunakan atau mengaplikasikan pengetahuan tersebut dalam kegiatan komunikasi. Seseorang siswa belum dapat dikatakan menguasai Bahasa Inggris jika belum dapat menggunakan Bahasa Inggris untuk keperluan komunikasi, meskipun dia mendapat nilai yang bagus pada penguasaan kosa kata dan tata bahasanya. Namun harus diakui bahwa seseorang tidak mungkin dapat berkomunikasi dengan baik jika dengan kosakata yang rendah.
Oleh sebab itu, penguasaan kosakata wajib diperlukan tetapi yang lebih penting bukan semata-mata pada penguasaan kosakata tersebut tetapi juga memanfaatkan pengetahuan kosakata tersebut dalam kegiatan komunikasi dengan Bahasa Inggris.

Dalam belajar bahasa, orang mengenal keterampilan resentif dan keterampilan produktif.Keterampilan resentif meliputi keterampilan menyimak (listening) dan keterampilan membaca (reading), sedangkan keterampilan produktif meliputi keterampilan berbicara (speaking) dan keterampilan menulis (writing). Baik keterampilan resentif maupun keterampilan produktif perlu dikembangkan dalam proses pembelajaran Bahasa Inggris. Agar dapat menguasai keterampilan tersebut diatas dengan baik, siswa perlu dibekali dengan unsur-unsur bahasa misalnya, kosakata dan tata bahasa. Penguasaan kosakata dan tata bahasa hanya merupakan salah satu unsur yang diperlukan dalam penguasaan keterampilan bahasa, khususnya dalam pembelajaran Bahasa Inggris.

Pembelajaran Bahasa Inggris sebagai bahasa asing hendaknya dikemas sedemikian rupa sehingga siswa merasa senang dan tertarik untuk mempelajarinya. Pembelajaran Bahasa Inggris di SMA seharusnya menjadi kegiatan yang menyenangkan, dikarenakan pada tingkat ini masih memiliki emosional yang dinamis. Kegiatan ini juga harus ditunjang dengan alat bantu mengajar yang menarik, misalnya gambar, video, animasi, software pembelajaran, dan media pembelajaran lainnya, agar mereka dapat belajar secara menyenangkan.

\section{Media Pembelajaran}

Pada pembelajaran, guru tidak lepas dari media pembelajaran karena media pembelajaran merupakan sebagai salah satu factor pembantu yang penting dalam proses mengajar. Keberhasilan guru dapatdilihat pada saat proses pembelajaran berlangsung, yaitu dalammentrasformasikan ilmu kepada siswa. Untuk mewujudkan prosespembelajaran yang efektif dan efisien maka seorang guru membutuhkansebuah alat bantuuntuk alat komunikasi.

Menurut Gagne \& Briggs (1979), Media Pembelajaran adalah berbagai komponen yang ada dalam lingkungan siswa dan dapat merangsang untuk belajar. Sedangkan menurut Sadiman (2014:6), media adalah perantara 
ataupengantar pesan dari pengirim ke penerima. Kata media berarti perantara:penghubung; yang terletak di antara dua pihak (orang, atau golongan).Kata "media" berasal dari bahasa latin dan merupakan bentuk jamak darikata medium yang berarti perantara.

Sesuai dengan perkembangan teknologi, para pakar pendidikan mencariberbagai cara guna mengembangkan sebuah media pembelajaran agar memudahkan siswa dalam belajar. Dengan media pembelajaran akanterjadi komunikasi antara guru dengan siswanya, sehingga prosespembelajaran akan berjalan lancar dengan hasil yang maksimal. Gagne'dan Briggs (1975) dalam buku yang dikutip Arsyad (2013:4),secara implisit mengatakan bahwa media pembelajaran meliputi alat yang secara fisikdigunakan untuk menyampaikan isi materi pembelajaran, seperti buku, tape recorder, kaset, video camera, video recorder, film,slide(gambar bingkai), foto, gambar, grafik, televisi, maupun komputer.

\section{Fungsi Media Pembelajaran}

Media pembelajaran merupakan alat bantuyang digunakan oleh orang (dalam hal ini adalah guru) untuk menyampaikan pesan kepada siswa. Sadiman (2014:17)berpendapat bahwa, secara umum media pembelajaran mempunyai fungsi memperjelas penyajian pesan agar tidakterlalu bersifat verbal, mengatasi keterbatasan ruang, waktu dan daya indera. Penggunaan media pembelajaran secara tepat dan bervariasi dapat mengatasi sikap pasif siswa. Dengansifat yang unik pada setiap siswa ditambah dengan lingkungan danpengalaman yang berbeda, sedang kurikulum dan materi pendidikanditentukan sama untuk setiap siswa, maka guru banyak mengalami kesulitan bilamana semua harus diatasi sendiri. Hal ini akan lebih sulitbila latar belakang lingkungan guru dengan siswa berbeda. Masalah ini dapat diatasi dengan media pembelajaran, yaitu dengan kemampuannyadalam memberikan perangsangan yang sama, menimbulkan persepsiyang sama.

Levie \& Lentz (1982) dalam Arsyad (2013:20),mengemukakan empat fungsi media pembelajaran, khususnya visual,yaitu: (a) fungsi atensi, (b) fungsi afektif, (c) fungsi kognitif, dan (d) fungsi kompensatoris.

\section{Media Pembelajaran Berbantuan Komputer}

Sebagaimana dengan perkembangan teknologi elektronik, membawa perubahanperubahanbesar dalam dunia pendidikan. Komputer sebagai mediapembelajaran dikenal dengan nama pembelajaran dengan bantuankomputer atau Computer-Asssisted Instruction (CAI). Sedangkankomputer sendiri menurut Arsyad (2013:54), adalah mesin yangdirancang khusus untuk memanipulasi informasi yang diberi kode, mesinelektronik yang otomatis melakukan pekerjaan dan perhitungan sederhanadan rumit. Penyajian pesan dan informasi dalam CAI dapat berbentuk:

1. Tutorial,

2. Permainan instruksional,

3. Drill and practice, dan

4. Simulasi.

Keuntungan dengan pemanfaatan komputer sebagai media pembelajaran menurut Arsyad (2013:55), adalah:

1. Komputer dapat mengakomodasikan siswa yang lamban menerimapelajaran,

2. Komputer dapat merangsang siswa untuk mengerjakan latihan,kegiatan laboratorium atau simulasi,

3. Kendali berada ditangan siswa sehingga tingkat kecepatan belajarsiswa dapat disesuaikan dengan tingkat penguasaannya,

4. Kemampuan merekam aktivitas siswa selama menggunakan suatuprogram pembelajaran memberi kesempatan lebih baik untukpembelajaran secara perorangan dan perkembangan setiap siswaselalu dapat dipantau.

5. Dapat berhubungan dengan, dan mengendalikan, peralatan lain seperticompact disc, video tape, dan lainlain dengan menggunakankomputer.

\section{Pengertian Multimedia}

Multimedia yaitu: "multi" dan "media", kata multimemiliki arti banyak atau lebih dari satu, sedangkan kata media berartisarana untuk berinteraksi dan berkomunikasi. Multimedia adalah sebuah alat atau sarana yang menggabungkan bebarapaunsur media.

Menurut Arsyad (2013:162), bahwa multimedia secara umumdiartikan sebagai lebih dari satu media yaitu kombinasi antara teks, grafik, animasi, suara, dan video.Penggabungan ini merupakan kesatuan yang secara bersamasamamenampilkan informasi, pesan atau isi 
pelajaran. Sedangkan menurut Vaughan (2004) dalam Binanto (2010:2),multimedia merupakan kombinasi teks, seni, suara, gambar, animasi, danvideo yang disampaikan menggunakan komputer secara interaktif.

Maka multimedia memiliki makna yaitumengkombinasikan berbagai macam teks, video, gambar, animasi, senidan suara yang digerakkan secara bersama-sama menggunakan sebuahteknologi komputer. Multimedia sendiri dapat dikontrolatau dikendalikan oleh pengguna, sehingga pengguna dapat mengatursesuai dengan selera dalam arti lain bahwa multimedia bersifat interaktifkarena melibatkan pengguna untuk menggerakkan.

\section{Interaktif}

Interaktif adalah sebuah kata sifat yangberasal dari kata interaksi yang artinya terdapat hubungan timbal-balik atau saling mempengaruhi. Jika kata interaktif dikaitkan dengan media, makainteraktif bersifat saling mempengaruhi. Artinya, antara pengguna (user)dan media (program) ada hubungan timbal balik, user memberikanrespon terhadap permintaan tampilan media (program), kemudiandilanjutkan dengan penyajian informasi atau konsep berikutnya yangdisajikan oleh media (program) tersebut.

Arsyad(2013:97) menjelaskan bahwa, interaksi dalam lingkungan pembelajaran berbasis komputer meliputi tiga unsur, yaitu:

1. Urutan-urutan instruksional yang dapat disesuaikan,

2. Jawaban atau respons atau pekerjaan siswa,

3. Umpan balik yang dapat disesuaikan.

\section{Pengertian Pembelajaran CTL}

Pembelajaran CTL merupakan suatu proses pembelajaran yangholistic dan bertujuan membantu siswa untuk memahami makna materipembelajaran yang dipelajarinya dengan mengkaitkan materi tersebutdengan konteks kehidupan sehari-hari (konteks pribadi, sosial, dankultural), sehingga siswa memiliki pengetahuan atau ketrampilan yangsecara fleksibel dapat diterapkan (ditransfer) dari satu permasalahan ataukonteks kepermasalahan lainnya.

Jhonson (2002) mengemukakan (Contextual teaching and learning is a system of instruction based on the philosophy that students learn when they see meaning in academic material, and they see meaning in schoolwork when they can connect new information with prior knowledge and their own experience)bahwa pembelajaran dan pengajarankontekstual melibatkan para siswa dalam aktivitas penting yang membantu mereka mengaitkan pelajaran akademis dengan konteks kehidupan nyata yang mereka hadapi. Dengan mengaitkan keduanya, siswa dapat melihat makna dalam tugas sekolah.

Menurut Sanjaya

(2006:253)

mendefinikan CTL sebagai suatu strategi pembelajaran yang menekankan kepada proses keterlibatansiswa secara penuh untuk menemukan materi yang dipelajari danmenghubungkannya dengan situasi kehidupan nyata.

\section{Karakteristik Pembelajaran Kontekstual}

Pembelajaran dalam CTL bukan berupa hafalan dan kemudian dilupakan, akan tetapi sebagai bekal mereka dalammengarungi kehidupan nyata. Menurut Sanjaya (2006:254) terdapatlima karakteristik penting dalam proses pembelajaran kontekstual, yaitu:

1. Pembelajaran merupakan proses pengaktifan pengetahuan yang sudahada (activiting knowledge), artinya apa yang akan dipelajari tidakterlepas dari pengetahuan yang sudah dipelajari, dengan demikianpengetahuan yang akan diperoleh siswa adalah pengetahuan yang utuhyang memiliki keruntutannya.

2. Pembelajaran kontekstual adalah belajar dalam rangka memperoleh danmenambah pengetahuan baru (acquiring knowledge). Pengetahuan baruitu diperoleh dengan cara deduktif, artinya pembelajaran dimulaidengan mempelajari secara keseluruhan, kemudian memperhatikandetailnya.

3. Pemahaman pengetahuan (understanding knowledge), artinyapengetahuan yang diperoleh siswa bukan untuk dihafal tetapi untukdipahami dan diyakini.

4. Mempraktikkan pengetahuan dan pengalaman tersebut (applyingknowledge), artinya pengetahuan dan pengelaman yang diperolehnyaharus diaplikasikan dalam kehidupan siswa, sehingga tampakperubahan perilaku siswa dalam kehidupan nyata.

5. Melakukan refleksi (reflecting knowledge) terhadap strategipengembangan pengetahuan. Hal ini dilakukan sebagai 
umpan balikuntuk proses perbaikan dan penyempurnaan strategi.

\section{Pendekatan Contextual Teaching and Learning(CTL)}

Hal ini menegaskan adanya keterkaitan bahan ajar dan kegiatan pembelajaran di kelas dengan situasi nyata dan pengalaman actual siswa yang berfokus pada proses pembelajarn yang menuntun siswa kearah berpikir kristis,kreatif,mampu memecahkan masalah, dan mampu menerapkan pengetahuannya dalam kehidupan keseharian, Sanjaya (2006:262). Pendekatan ini menerapkan prinsip-prinsip berikut:

1) Inquiry: kegiatan pembelajaran dengan prinsip sebagai berikut:

a. Diawali dengan pengamatan dan bergerak kepemahaman konsep atau fenomena.

b. Proses bersiklus mulai dari pengamatan, bertanya, meneliti, menganalisis, dan menjelaskan baik secara individual dan kelompok.

c. Mengembangkan dan menerapkan keterampilan berpikir kritis dalam pembelajaran.

2) Questioning: Ketermpilanbertanya:

a. Digunakanolehguruuntukmengarahkan, menuntundanmenilaisiswa.

b. Digunakansiswasepanjangkegiatanbelaj arberbasisinkuiri.

3) Constructivism.

Prinsipinimengindikasikanpembelajarandik elasharus:

a. Membangun pemahaman akan makna dari sudut pengalaman yang didasarkan pada pengetahuan awal siswa.

b. Pengembangan pemahaman mendalam melalui cara mengaitkan pelajaran dengan pengetahuan dan pengalamannya.

4) Learning Community. Prinsip ini mengindikasikan kegiatan pembelajaran harus diwarnai:

a. Berbicara dan bertuka rpikiran

b. Bekerjasama antara guru siswa dan siswa dengan siswa untuk membangun kegiatan pembelajaran yang lebih baik dibandingkan bila hanya dilakukan sendirian.

5) Penilaian otentik.Penilaian pembelajaran yang otentik mencakup hal berikut:

a. Mengukur pengetahuan keterampilan siswa

b. Menuntut penerapan pengetahuan

c. Menilai hasil atau performani siswa

d. Tugas-tugas belajar yang dinilai harus relevan dan berkait dengan konteks

e. Baikprosesmaupunprodukkeduanyadinil ai

6) Reflection.Kegiataninimemberikanpeluang kepadasiswauntukmelakukanrefleksi, penilaianatasapayangdipelajarinyasehingga tahupersiskekuatandankelamahannya.

Melaluirefleksidapatteridentifikasi:
a. cara-cara berpikirtentangapa yangtelahdipelajari

b. mereviudanmerespon peristiwa,kegiatan,danpengalaman

c. merekam apa yang telah dipelajari, apa yang dirasakan,dan merekam pikiran baru

d. bentuk penilainnya dapat berupa: jurnal,diskusi,karya siswadll.

7) Modelling.

Pemberiancontohataumodeldalampe

mbelajaranbahasa khususnya keterampilanberkomunikasisangatpenting.I nidapatdilakukanantara lain:

a. Mengungkapkantentangprosesbelajaryangse dangdialami (thinkingaloud)

b. Mendemonstrasikanapa

yangingindipelajarisiswa

c. Melakukanapayangakandilakukanolehsisw a.

Berdasarkan latar belakang dan batasan masalah di atas, maka masalah penelitian dirumuskan yaitu apakah media pembelajaran interaktif berbasis CTL Layak digunakan dalam pembelajaran Bahasa Inggris SMA kelas XI.

\section{METODE}

Penelitian pengembangan media pembelajaran interaktif berbasis Contextual Teaching Learning (CTL) pada bidang studi Bahasa Inggris dilaksanakan di SMA Negeri 20 Medan. Metode penelitian yang digunakan adalah research and development, karena penelitian ini termasuk penelitian pengembangan pendidikan yang bertujuan untuk menghasilkan media pembelajaran yang layak dimanfaatkan dan sesuai kebutuhan pembelajaran. Borg dan Gall (1983) memberikan batasan tentang penelitian pengembangan sebagai usaha untuk mengembangkan dan memvalidasi produkdan produk yang digunakan dalam pendidikan. 
Pengertian yang hampir sama dikemukakan oleh Asim dalam Waldopo (2002: 1) bahwa penelitian pengembangan dalam pembelajaran adalah proses yang digunakan untuk mengembangkan dan memvalidasi produkproduk yang digunakan dalam proses pembelajaran.

Model pengembangan pada penelitian ini adalah penelitian pengembangan yang akan menghasilkan produk berupa media pembelajaran interaktif berdasarkan temuan uji di lapangan. Borg \& Gall dalam Sugiyono (2013:9) menyatakan bahwa penelitian dan pengembangan (Research and Development/ $R \& D)$ merupakan model penelitian yang digunakan untuk mengembangkan dan memvalidasi produk-produk yang digunakan dalam pendidikan dan pembelajaran. Penelitian dan pengembangan merupakan "jembatan" antara penelitian dasar (basic reserach) dengan penelitian terapan (applied research), dimana penelitian dasar bertujuan untuk "to discover new knowledge about fundamental phenomena" dan applied research bertujuan untuk menemukan pengetahuan yang secara praktis dapat diaplikasikan. Walaupun kadang-kadang penelitian terapan juga untuk mengembangkan produk.

\section{Instrumen Pengumpulan Data}

Instrumen pengumpulan data pada pengembangan ini berupa instrumen penilaian untuk menilai produk yang telah dikembangkan. Instrumen pokok yang dipakai untuk mengumpulkan data dalam pengembangan ini adalah sebagai berikut :

\section{Lembar Angket}

Instrumen yang digunakan dalam penelitian ini adalah (1) lembar angket untuk ahli materi, (2) lembar angket untuk ahli desain pembelajaran dan ahli media, dan (3) lembar angket untuk siswa. Lembar angket yang pertama digunakan untuk memperoleh data tentang kualitas materi pembelajaran dan pengembangan aspek sistem penyampaian pembelajaran yang diisi oleh ahli bidang
Bahasa Inggris. Lembar angket yang kedua digunakan untuk memperoleh data tentang kualitas desain pembelajaran dan teknis dari produk yang berupa $\mathrm{CD}$ pembelajaran serta kualitas oleh ahli desain pembelajaran dan ahli media. Lembar angket yang ketiga digunakan untuk memperoleh data tentang kualitas CD pembelajaran dari peserta didik.

\section{Lembar Wawancara}

Lembar wawancara dipakai sebagai alat pengumpulan data dari ahli materi sehubungan dengan saran, kritik dan masalah-masalah serta siswa SMA Negeri 20 Medan pada saat uji coba satu-satu, kelompok kecil dan uji coba lapangan. Wawancara dilakukan pada saat pelaksanaan uji coba, baik melalui angket terbuka maupun catatan langsung pada produk hasil pengembangan. Selain itu juga kepada guru maupun siswa berkaitan dengan validitas isi dengan jawaban mereka yang masih memerlukan penjelasan tambahan.

\section{Teknik Analisis Data}

Analisis data dalam penelitian ini menggunakan analisis deskriptif kuantitatif. Semua data yang terkumpul dianalisis dengan teknik statistik deskriptif yang secara kuantitatif dipisahkan menurut kategori untuk mempertajam penilaian dalam menarik kesimpulan. Data kualitatif yang berupa pernyataan sangat kurang layak, kurang layak, sedang, layak dan sangat layak diubah menjadi data kuantitatif dengan skala 1 sampai 5 . Hasilnya dirata-rata dan digunakan untuk menilai kualitas software pembelajaran. Kriteria software akan dikonversikan menjadi nilai dengan skala lima menggunakan Skala Likert yang dianalisis secara deskriptif persentase dengan rumus sebagai berikut Sugiyono, (2011:318):

$$
=\frac{\mathrm{X}}{\text { jumlah skor yang diperoleh }} \times 100 \%
$$

Dengan kriteria penilaian seperti yang tertulis pada tabel 4 berikut ini.

Tabel 1. Kriteria Penilaian

\begin{tabular}{|c|c|c|}
\hline Nilai & Kriteria & Persentase \\
\hline 5 & Sangat Baik & $81 \% \leq \mathrm{X} \leq 100 \%$ \\
\hline 4 & Baik & $61 \% \leq \mathrm{X} \leq 80 \%$ \\
\hline 3 & Sedang & $41 \% \leq \mathrm{X} \leq 60 \%$ \\
\hline 2 & Kurang Baik & $21 \% \leq \mathrm{X} \leq 40 \%$ \\
\hline 1 & Sangat Kurang & $0 \% \leq \mathrm{X} \leq 20 \%$ \\
\hline
\end{tabular}

Keterangan : $\mathrm{X}=$ Skor Empiris 


\section{HASIL DAN PEMBAHASAN \\ Data Hasil Uji Coba Produk Uji Coba Kelompok Kecil (Small Group Trying Out)}

Uji coba kelompok kecil dilaksanakan setelah peneliti melakukan revisi berdasarkan hasil validasi ahli desain dan guru. Uji coba kelompok kecil dilakukan dengan melakukan simulasi kepada 16 siswa SMA N 20 Medan kelas XI yang diambil secara acak. Komputer kemudian peneliti menjelaskan tentang gambaran media interaktif secara keseluruhan dan selanjutnya peneliti menyuruh siswa untuk menggunakan media interaktif.

Hasil penilaian pada uji coba kelompok kecil meliputi aspek isi materi, pembelajaran, tampilan dan penyajian serta aspek pemrograman. Hasil penilaian siswa pada uji kelompok kecil dapat dilihat pada Lampiran 17.

\section{Uji Coba Lapangan (Field Trying Out)}

Tahap uji coba lapangan merupakan tahap akhir dari langkah validasi dan evaluasi media interaktif Bahasa Inggris SMA. Uji coba lapangan dilakukan di SMA Negeri 20 Medan, pada kelas XI. IS.2. Keseluruhan subyek dalam uji coba lapangan sebanyak 40 siswa.

Pelaksanaan uji coba lapangan dilakukan dengan cara mengimplementasikan media interaktif yang telah dikembangkan dalam pembelajaran di kelas. Pembelajaran yang dilakukan yaitu siswa diberikan pengenalan tentang media interaktif yang telah dikembangkan kemudian guru memberikan gambaran materi yang akan dipelajari dalam media. Setelah selesai mempelajari media, siswa diberikan kesempatan untuk bertanya dan berlatih soal. Untuk mengetahui sejauh mana siswa memahami materi yang dipelajari, maka siswa mengerjakan evaluasi. Hal terakhir yang dilakukan siswa adalah menilai media interaktif tersebut serta memberi komentar dan saran.

Hasil penilaian yang dilakukan siswa pada uji coba lapangan digunakan untuk menyempurnakan produk akhir dari media pembelajaran media interaktif Bahasa Inggris sebagai penunjang pembelajaran kontekstual di SMA. Data penilaian siswa uji coba lapangan meliputi empat aspek yaitu aspek isi materi, aspek pembelajaran, aspek tampilan dan penyajian serta aspek pemrograman. Hasil penilaian siswa uji coba lapangan ditinjau dari aspek isi materi dapat dilihat pada Lampiran 17.

\section{Analisis Data \\ Analisis Data Hasil Validasi}

Analisis data hasil validasi produk dilakukan terhadap data hasil penilaian oleh ahli materi, ahli media, ahli desain dan guru. Aspek penilaian meliputi aspek isi materi, aspek pembelajaran, aspek tampilan dan penyajian, serta aspek pemrograman. Ahli materi menilai dari isi materi dan aspek pembelajaran Bahasa Inggris dalam media interaktif serta pendapat kesesuaian media interaktif yang menunjang pembelajaran kontekstual, sedangkan ahli media menilai dari aspek tampilan, penyajian, aspek pemrograman dalam media interaktif dan pendapat kesesuaian media interaktif yang menunjang pembelajaran kontekstual, serta ahli desain menilai dari hal-hal yang terkait dengan kesesuaian kisi-kisi instrumen, penyusunan instrumen, kualitas tampilan, aspek pemrograman, pendapat mengenai kesesuaian media dengan pembelajaran kontekstual, bahasa dan kata-kata yang benar serta mudah dipahami dalam melakukan desain pembelajaran, kemudian guru sebagai calon pengguna dan praktisi menilai media dari aspek isi materi, aspek pembelajaran, tampilan dan penyajian, aspek pemrograman serta memberikan pendapat kesesuaian media interaktif yang menunjang pembelajaran kontekstual. Adapun analisis data terhadap keempat aspek adalah:

\section{Analisis Data Hasil Evaluasi Produk dari Kelayakan Materi}

Data kelayakan materi pada tahap validasi diperoleh dari ahli materi dan guru. Data hasil validasi dari kelayakan materi ditinjau dari dua aspek yaitu aspek isi materi dan aspek pembelajaran serta pendapat kesesuaian media interaktif yang menunjang pembelajaran kontekstual. Berdasarkan pada Lampiran 15, diketahui bahwa media interaktif Bahasa Inggris yang dikembangkan ditinjau dari kelayakan aspek isi materi oleh Ahli Materi I diperoleh rerata skor sebesar 4.54 dengan tingkat persentase kelayakan $90.83 \%$. Jika dilihat pada Tabel 3.6 sebagai pedoman Interval skor penilaian dengan lima kategori, penilaian ahli materi pada kelayakan isi, penyajian, kebahasaan, kegrafikan mendapat kategori "Layak". Sedangkan hasil penilaian dari Ahli Materi II terhadap isi materi diperoleh rata-rata skor sebesar 4.42 dengan tingkat persentase kelayakan $88.33 \%$. Jika dilihat pada Tabel 3.6 sebagai pedoman Interval skor penilaian dengan 
lima kategori, penilaian Ahli Materi II pada kelayakan isi, penyajian, kebahasaan, kegrafikan termasuk kategori "Layak" juga.

Berdasarkan penilaian Ahli Materi I, peneliti menyoroti nilai paling rendah dengan rerata skor sebesar 4.33 yang termasuk pada kategori "Layak". Penilaian ini terdapat pada indikator kelayakan isi, terdapat muatan aspek afektif dan bahasa yang digunakan mudah dipahami. Sedangkan penilaian Ahli Materi II juga menyoroti nilai paling rendah dengan rerata skor sebesar 4.13 dengan kategori "Layak" terdapat pada indikator kelayakan isi juga. Hal tersebut menjadi perhatian peneliti dalam merevisi produk.

Berdasarkan pada Lampiran 18, penilaian media interaktif ditinjau dari Penyajian dan Kebahasaan oleh Ahli Materi I diperoleh rata-rata skor sebesar 4.67 dengan tingkat persentase kelayakan $93.40 \%$. Sedangkan penilaian Ahli Materi II pada aspek Kebahasaan dengan rata-rata skor 4.67 dengan tingkat persentase kelayakan $93.40 \%$. Jika dilihat pada pedoman konversi rerata skor, penilaian kedua Ahli Materi pada kelayakan pembelajaran mendapat kategori "Layak".

\section{Analisis Data Hasil Evaluasi Produk dari Kelayakan Media}

Kelayakan media dalam tahap validasi dinilai oleh masing-masing Ahli Media. Data hasil validasi dari kelayakan media ditinjau dari empat aspek yaitu aspek kelayakan isi, penyajian, kebahasaan serta aspek kegrafikan. Berdasarkan pada Lampiran 18, diketahui bahwa media interaktif Bahasa Inggris yang dikembangkan ditinjau dari kelayakan aspek kelayakan isi, penyajian, kebahasaan serta aspek kegrafikan oleh Ahli Media I diperoleh rata-rata skor 4.54 dengan tingkat persentase kelayakan 90.83\%. Sedangkan Ahli Media II diperoleh rata-rata skor 4.42 dengan tingkat persentase kelayakan $88.33 \%$. Jika dilihat pada Tabel 3.6 sebagai pedoman konversi rerata skor, masing-masing ahli media pada kelayakan aspek tampilan dan penyajian mendapat kategori "Layak".

\section{Analisis Data Hasil Evaluasi Produk dari Kelayakan Desain}

Kelayakan media dalam tahap validasi dinilai oleh masing-masing ahli desain pembelajaran. Data hasil validasi dari kelayakan desain ditinjau dari aspek desain pembelajaran. Berdasarkan pada Lampiran 5, diketahui bahwa media interaktif Bahasa Inggris yang dikembangkan ditinjau dari kelayakan aspek desain pembelajaran oleh ahli desain diperoleh rata-rata skor 3.78 dengan tingkat persentase kelayakan $75.56 \%$. Jika dilihat pada Tabel 3.6 sebagai pedoman konversi rerata skor, penilaian ahli desain memberikan nilai kelayakan kategori "Layak".

\section{Analisis Data Media yang Menunjang Pembelajaran CTL}

Pengembangan media pembelajaran interaktif pada mata pelajaran Bahasa Inggris kelas XI guna menunjang pembelajaran kontekstual di SMA merupakan tujuan peneliti dalam menyusun produk. Teori belajar kontekstual (CTL) merupakan pendekatan yang digunakan dalam membuat media interaktif. Peneliti mengukur serta mengetahui kesesuaian media pembelajaran interaktif yang menunjang pembelajaran CTL melalui penilaian pendapat para ahli dan guru SMA. Peneliti meminta ahli materi, ahli media, dan ahli desain untuk memberikan pendapat mereka mengenai media interaktif yang telah dikembangkan guna menunjang dalam pembelajaran kontekstual di SMA. Rata-rata skor dari ahli materi, ahli media dan ahli desain dapat dilihat pada Tabel 2 berikut:

Tabel 2. Pendapat Ahli Materi, Ahli Media, dan Guru SMA mengenai Media Interaktif Bahasa Inggris yang Menunjang CTL

\begin{tabular}{|c|l|c|c|c|}
\hline No. & \multicolumn{1}{|c|}{ Validator } & P\% & Rata-rata & Kategori \\
\hline 1 & Ahli Materi & $89.58 \%$ & 4.48 & Layak \\
\hline 2 & Ahli Media & $85.36 \%$ & 4.27 & Layak \\
\hline 3 & Ahli Desain & $75.56 \%$ & 3.78 & Layak \\
\hline
\end{tabular}

Dengan pedoman Tabel 2 tentang konversi rerata skor kategori lima, pendapat ahli materi, dan ahli desain berpendapat "Layak". Media pembelajaran interaktif dapat menunjang pembelajaran kontekstual (CTL) apabila pendapat ahli minimal termasuk dalam kategori "Layak". Berdasarkan pendapat ketiganya, maka media interaktif Bahasa 
Inggris yang telah dikembangkan sudah menunjang dalam pembelajaran kontekstual yang tentunya dapat diterapkan di kelas maupun dalam belajar mandiri.

Keseluruhan penilaian validator dilihat dariempat aspek yaitu aspek kelayakan isi, penyajian, kebahasaan serta aspek kegrafikan diperoleh hasil dengan kategori lebih dari
"Layak". Oleh karena itu, media interaktif yang dikembangkan dikatakan "Layak" digunakan dalam pembelajaran dan menunjang pembelajaran kontekstual (CTL) sesuai dengan kategori yang sudah ditentukan. Persentase rerata skor penilaian kelayakan tiap aspek dan pendapat ahli serta guru dapat dilihat pada Tabel 3 berikut:

Tabel 3. Rerata Skor Penilaian Kelayakan Tiap Aspek dan Pendapat Ahli

\begin{tabular}{|c|l|c|c|c|}
\hline \multirow{2}{*}{ No } & \multicolumn{2}{|c|}{ Penilaian } & \multicolumn{3}{|c|}{ Validator } \\
\cline { 3 - 5 } & & Ahli Materi & Ahli Media & Ahli Desain \\
\hline 1 & Aspek Kelayakan Isi & 4.25 & 4.25 & - \\
\hline 2 & Aspek Penyajian & 4.67 & 4.29 & - \\
\hline 3 & Aspek Kebahasaan & 4.50 & - & - \\
\hline 4 & Aspek Kegrafikan & 4.50 & - & - \\
\hline 5 & Aspek Pembuka & - & - & 3.67 \\
\hline 6 & Aspek Inti & - & - & 3.83 \\
\hline 7 & Aspek Penutup & - & - & 3.83 \\
\hline
\end{tabular}

Persentase rerata skor di atas menunjukkan perbandingan hasil penelitian masing-masing aspek dan pendapat validator. Pada tahap validasi, aspek yang memperolah penilaian tertinggi adalah aspek penyajian berdasarkan penilaian ahli materi yaitu sebesar 93.33\% kemudian pendapat ahli desain memperoleh nilai paling rendah sebesar $73.33 \%$ pada aspek pembuka. Hal ini dapat dijadikan sebagai dasar untuk menafsirkan bahwa aspek desain pembelajaran perlu ditingkatkan kualitasnya diantara aspek yang lainnya agar lebih baik.

\section{Analisis Data Hasil Uji Coba}

Analisis hasil uji coba pada pengembangan media interaktif ini dibagi menjadi dua tahap, yaitu tahap uji coba kelompok kecil dan tahap ujicoba lapangan. Media interaktif yang telah dikembangkan diujicobakan dalam pembelajaran Bahasa Inggris di kelas kemudian siswa menilai serta memberikan masukan terhadap media tersebut. Uji coba kelompok kecil dilakukan untuk mengidentifikasi permasalahan awal yang terjadi ketika media pembelajaran digunakan. Sedangkan uji coba lapangan dijadikan pedoman dalam merevisi produk agar tidak ditemukan permasalahan dasar yang mengganggu pembelajaran hingga dihasilkan produk akhir. Disamping itu, kedua tahap tersebut digunakan sebagai penilaian kualitas atau kelayakan media. Kelayakan produk pada uji coba terdiri atas dua aspek penilaian yaitu aspek kelayakan isi, dan aspek kegrafikan. Berikut ini analisis hasil penilaian pada tahap uji coba.

\section{Analisis Data Uji Coba dari Kelayakan Materi dan Aspek Pembelajaran}

Hasil uji coba kelompok kecil dan uji coba lapangan berupa skor penilaian yang kemudian diolah ke dalam bentuk klasifikasi reliabilitas. Data penilaian pada uji coba kelompok kecil ditinjau dari kelayakan aspek kelayakan isi diperoleh sebesar 3.66. Sedangkan pada uji kelompok besar/ uji coba lapangan, penilaian aspek kelayakan isi mendapat persentase kelayakan sebesar 3.68. Aspek kegrafikan pada uji coba kelompok kecil sebesar 3.63, dan pada uji kelompok besar / uji coba lapangan dari kelayakan aspek kegrafikan sebesar 3.63 termasuk kategori "Layak". Jika dilihat pada Tabel 3.7 pedoman klasifikasi reliabilitas skala lima dari uji coba kelompok kecil dan uji coba lapangan mendapat kriteria "Layak" Terdapat pada Lampiran 18.

\section{Hasil Penelitian Pengembangan Produk}

Media pembelajaran interaktif menyediakan peluang bagi pendidik untuk mengembangkan teknik pembelajaran sehingga menghasilkan hasil yang maksimal. Demikian juga bagi peserta didik, dengan media pembelajaran interaktif diharapkan mereka akan lebih mudah untuk menentukan dengan apa dan 
bagaiamana siswa dapat menyerap informasi secara cepat dan efisien. Sumber informasi tidak lagi terfokus pada teks dari buku tetapi lebih luas dari itu seperti penggunaan komputer atau laptop sebagai sumber informasi. Kemampuan teknologi media yang semakin baik dan berkembang akan menambah kemudahan dalam mendapatkan pengetahuan siswa. Sagala (2003) menjelaskan bahwa pembelajaran interaktif mempunyai dua karakteristik yaitu: (1) dalam proses pembelajaran melibatkan proses mental siswa secara maksimal, bukan hanya menuntut siswa sekedar mencatat, akan tetapi menghendaki aktivitas siswa dalam proses berpikir, (2) dalam pembelajaran membangun suasan dialogis dan proses Tanya jawab terus menerus yang diarahkan untuk memperbaiki dan meningkatkan kemampuan siswa untuk memperoleh pengetahuan yang mereka kontruksi sendiri. Produk pengembangan media pembelajaran interaktif pada mata pelajaran Bahasa Inggris ini adalah salah satunya dan merupakan materi pelajaran yang telah dikembangkan dengan memperhatikan aspek pembelajaran dan media sebagai prinsip desain pesan pembelajaran. Penelitian pengembangan produk yang dilakukan ini diarahkan untuk menghasilkan suatu produk berupa media pembelajaran interaktif pada mata pelajaran Bahasa Inggris untuk siswa SMA khususnya SMA Negeri 20 Medan yang digunakan untuk meningkatkan kualitas proses pembelajaran dan kompetensi siswa. Oleh sebab itu proses penelitian ini dilakukan dan diawali dengan (1) studi pendahuluan; (2) kemudian mendesain media pembelajaran; (3) melakukan validasi produk kepada ahli materi, ahli desain pembelajaran dan ahli rekayasa perangkat lunak; (4) melakukan revisi dan penyempurnaan berdasarkan analisis data validasi dari tenaga ahli; (5) melakukan uji coba terhadap siswa selaku pengguna media; (6) melakukan revisi berdasarkan hasil uji coba terhadap siswa; (7) melakukan uji keefektifan produk sehingga dihasilkan media pembelajaran yang layak digunakan sesuai dengan karakteristik bidang studi dan siswa sebagai pengguna.

Aspek yang direvisi dan disempurnakan berdasarkan analisis data dan uji coba serta masukan dari ahli materi ahli desain pembelajaran dan ahli rekayasa perangkat lunak bertujuan untuk menggali beberapa aspek yang lazim dalam proses pengembangan produk.
Variabel-variabel penilaian media pembelajaran memiliki nilai rata-rata yang sangat sesuai.

Berdasarkan data hasil validasi ahli materi, ahli desain pembelajaran dan ahli rekayasa perangkat lunak diperoleh penilaian dengan kriteria Layak dengan beberapa saran perbaikan. Selanjutnya data hasil uji coba yang dilakukan terhadap siswa yang meliputi uji coba perorangan, uji coba kelompok kecil dan uji coba lapangan diperoleh hasil penilaian dengan kriteria Layak. Secara keseluruhan hasil validasi uji coba pengembangan media pembelajaran interaktif ini memperoleh penilaian Layak yang berarti bahwa media pembelajaran interaktif pada mata pelajaran Bahasa Inggris Layak digunakan untuk meningkatkan kualitas proses pembelajaran dan kompetensi siswa. Media pembelajaran interaktif pada proses pembelajaran sudah Layak untuk digunakan sebagai salah satu alternatif media pembelajaran yang telah ada.

Hal ini didukung oleh penemuan sebelumnya Lingin (2012:53) yang menyatakan bahwa penggunaan media pembelajaran interaktif dengan menggunakan macromedia flash layak untuk digunakan dimana didalam media pembelajaran banyak disisipkan animasi media sehingga menimbulkan ketertarikan pada siswa untuk belajar. Penggunaan media pembelajaran interaktif layak dalam hal berikut: (1) layak dalam hal kepraktisan, misalnya siswa sebagai pengguna mampu dengan mudah menggunakan media pembelajaran dengan mengikuti semua perintah yang ada dalam media pembelajaran dan mengefisiensikan waktu dalam hal menjelaskan materi pembelajaran.

Penggunaan media pembelajaran interaktif akan memotivasi siswa untuk mengulang kembali materi pembelajaran dengan menggunakan media interaktif sehingga mempercepat pemahaman siswa terhadap materi pembelajaran Bahasa Inggris. (2) layak dalam hal teknis, misalnya layak dalam penyampaian materi, yaitu dengan menggunakan media pembelajaran interaktif materi yang disampaikan sesuai dengan kebutuhan para siswa dan sesuai dengan kurikulum pembelajaran yang telah ditetapkan oleh pemerintah serta dengan penggunaan media pembelajaran interaktif dapat memperjelas materi pembelajaran sehingga mudah dipahami oleh semua siswa serta (3) layak dalam hal visual atau tampilan media pembelajaran interaktif akan menciptakan 
desain, animasi yang menarik sehingga akan memotivasi.

Selanjutnya, hasil penelitian Susana (2013), menyimpulkan bahwa multimedia yang dikembangkan membentuk mental untuk belajar secara mandiri dan menyenangkan serta membangun konsep belajar untuk dirinya sendiri, sehingga penggunaan multimedia dalam pembelajaran ini menunjukkan antusias siswa untuk belajar, pengulangan dalam pembelajaran, siswa tidak malu belajar, dan juga terjadi perubahan tingkah laku yang besar, sehingga guru berperan sebagai fasilitator.

Manfaat penggunaan media pembelajaran interaktif pada mata pelajaran Bahasa Inggris adalah sebagai berikut: (1) materi mudah dipahami karena konsep yang disajikan direncanakan untuk mempermudah siswa dan sistematis; (2) media pembelajaran interaktif pada mata pelajaran Bahasa Inggris memberi kesempatan siswa untuk belajar sesuai dengan kecepatan masing-masing individu; (3) belajar lebih cepat dan menarik sehingga tidak menimbulkan kejenuhan karena dilengkapi dengan gambar-gambar dan animasi serta soal latihan yang bervariasi; (4) media pembelajaran interaktif ini juga dapat digunakan sebagai alternatif media pembelajaran secara individu.

\section{PENUTUP}

Berdasarkan dari hasil yang telah dicapai dari keseluruhan proses penelitian pengembangan media pembelajaran, maka dapat disimpulkan bahwa:

1. Pengembangan media pembelajaran interaktif telah dikembangkan sesuai dengan prosedur pengembangan dengan langkah 1) potensi dan masalah; 2) pengumpulan bahan; 3) desain produk (desain software atau program dan assembly,) pada tahap desain program meliputi desain alur kerja dan desain struktural; 4) validasi desain; 5) revisi desain; 6) uji coba produk; 7) revisi produk; 8) produksi media.

2. Pengembangan media pembelajaran ditinjau dari aspek isi materi, aspek pembelajaran, aspek penyajian dan tampilan, serta aspek pemrograman "Layak" digunakan dalam pembelajaran bahasa Inggris di SMA.

3. Pendapat ahli materi mengenai media pembelajaran yang menunjang pembelajaran kontekstual termasuk dalam kategori "Setuju", sedangkan pendapat ahli materi, ahli media dan guru bahasa Inggris di SMA Negeri 20 Medan termasuk dalam kategori "Layak". Berdasarkan pendapat dari validator tersebut, maka disimpulkan bahwa media pembelajaran interaktif yang dikembangkan telah menunjang pelaksanaan pembelajaran kontekstual.

\section{DAFTAR PUSTAKA}

Arsyad, A. 2013. Media Pembelajaran. Jakarta: PT. RajaGrafindo Persada

Binanto, I. 2010. Multimedia Digital-Dasar Teori dan Pengembangannya. Yogyakarta: CV ANDI OFFSET

Borg, W.R., Gall, M.D.,\& Gall, J.P. 2005. Educational Research An Introduction (4thed). New York: Longman

Dick, W., Carey, L. And Carey, J. O. (2009). The Systematic Design of Instruction (7th Ed.). New Jersey: Pearson.

Jhonson, E.B. 2002. Contextual Teaching And Learning. What It Is And Why It's Here To Stay. Teaching - United States. Learning Psychology.

Sagala, Syaiful. 2003. Konsep dan Makna Pembelajaran. Bandung: Alfabeta.

Sanjaya, W. 2006. Strategi Pembelajaran Berorientasi Standar Proses Pendidikan. Jakarta: Kencana Prenada Media Group

Sugiyono. 2013. Metode Penelitian Pendidikan (Pendekatan Kuantitatif, Kualitatif dan R\&D). Bandung: ALFABETA

Waldopo. (2002). Penelitian dan pengembangan, pendekatan dalam mengembangkan produk-produk di bidang pendidikan dan pembelajaran. Sebuah Kajian Singkat pada Jurnal Teknodik. No II/VI/Teknodik. Jakarta: Pustekom. 